\title{
Amobilisasi Inulinase Aspergillus clavatus Gmn 11.3 Galur Lokal Indonesia dengan Matrik Karbon Aktif
}

\author{
Saryono, Henny Olivia R.M., Elvita Sepriana, Andi Dahliati, dan Chainulfiffah A.M. \\ Jurusan Kimia FMIPA, Universitas Riau, Pekanbaru 28293 \\ Diterima 12-01-2007 Disetujui 16-08-2007
}

\begin{abstract}
Two types of inulinase are produced by Aspergillus clavatus Gmn 11.3 within the $3^{\text {rd }}$ and $5^{\text {th }}$ days of fermentation. The optimum condition of two types of immobilized inulinase is achieved using 20 grams of activated carbon, 200 meshes with protein adsorption of $96.71 \%$ and $96.19 \%$ respectively. Following immobilization of inulinase, incubation was carried out for 30 hours to hydrolyze inulin. After incubation, the proteins retained on the matrix are $66.96 \%$ of the 3 days fermentation enzymes and $37.36 \%$ for 5 days of fermentation enzyme.
\end{abstract}

Keywords: carbon active, immobilize, inulin, inulinase.

\section{PENDAHULUAN}

Aspergillus clavatus Gmn 11.3 adalah kapang koleksi Laboratorium Biokimia Fakultas Matematika dan Ilmu Pengetahuan Alam, Universitas Riau. Kapang ini diisolasi dari umbi dahlia (Dahlia variabilis) yang berasal dari Brastagi Sumatra Utara. Hasil penelitian pendahuluan mendapatkan bahwa Aspegillus clavatus Gmn 11.3 selain memiliki aktivitas laktase juga aktivitas inulinase yang cukup tinggi (Saryono 2002).

Inulinase adalah enzim hidrolitik yang mengkatalisis reaksi hidrolisis polisakarida (polifruktosa) inulin menjadi fruktosa yang dikenal dengan sirup fruktosa (HFS) dan atau fruktooligosakarida (FOS). Polifruktosa inulin di Indonesia banyak ditemukan pada umbi dahlia yang sampai saat ini belum dimanfaatkan secara optimal. Selain itu, sampai saat ini Indonesia masih menjadi negara pengimpor gula termasuk fruktosa. Oleh sebab itu, riset tentang inulinase perlu terus dikembangkan agar pengaplikasiannya dapat lebih cepat diterapkan. Enzim ini dapat dihasilkan oleh bakteri, jamur, maupun tumbuh-tumbuhan. Pada penelitian ini produksi inulinase dilakukan dengan menggunakan kapang Aspergillus clavatus Gmn 11.3 dalam media yang mengandung inulin sebagai induser (Saryono et al, 1999).

Penggunaan enzim secara langsung memiliki beberapa kelemahan, seperti tercampurnya produk dengan reaktan dan memerlukan teknik pemisahan yang relatif rumit, penggunaan enzim hanya satu kali saja sehingga produksi menjadi lebih mahal. Salah satu teknik untuk mengatasi masalah tersebut adalah dengan teknik amobilisasi enzim (Winarno 2002)

Enzim/sel amobil adalah suatu enzim yang secara fisik maupun kimia tidak bebas bergerak sehingga dapat dikendalikan atau diatur kapan enzim harus kontak dengan substratnya. Salah satu metode amobilisasi enzim adalah secara adsorpsi fisika, dimana enzim di jebak di dalam bahan pendukung yang tidak larut dalam air. Babarapa bahan pendukung (adsorben) yang dapat digunakan pada metode adsorpsi fisika adalah karbon aktif, gelas, tanah liat, alumina, silica gel, bentonite, kanji, tannin-aminohexyl cellulose, concanavalin Asepharose (Chibata 1978; Mangunwidjayja et al, 1992).

Pada penelitian ini, inulinase dari Aspergillus clavatus Gmn11.3 diamobilisi dengan metode adsorpsi fisika menggunakan karbon aktif sebagai matrik pendukung. Pemilihan matrik ini didasari karena inulin hanya dapat larut dalam air panas $\left( \pm 80^{\circ} \mathrm{C}\right)$, oleh sebab itu dibutuhkan matrik yang relatif tahan panas seperti karbon aktif, agar reaksi hidrolisis dapat berlangsung lebih sempurna.

\section{BAHAN DAN METODE}

Alat yang digunakan adalah alat-alat gelas, Spektrofotometer genesis II keluaran Milton Roy Co. USA, Autoklaf 1925x, Laminar flow EHC3, pH meter 210 A Orion, penangas air, timbangan analitik, sentrifuga, Water Bath Shaker WS-120, kolom kromatografi bermantel berukuran $\theta 1 \times 40 \mathrm{~cm}$. Bahan yang digunakan adalah jamur Aspergillus clavatus Gmm 11.3 koleksi Lab. Biokimia FMIPA UNRI yang 
diisolasi dari tanaman dahlia yang berasal dari daerah Brastagi. Bahan kimia: inulin, enzim inulinase, karbon aktif koleksi dari Lab. Kimia fisik FMIPA-UNRI dengan mesh $85<A<200$, kantong dialisis (MWCO 60008000, Reorder no 132665), Polietilen glikol 35000 (PEG 35000 yaitu PEG dengan bobot molekul 35000), dan bahan kimia lain adalah proanalisis, kecuali bila disebutkan lain.

Tahapan Penelitian. Penelitian ini merupakan riset ekploratif dimana pada pra-penelitian dilakukan untuk mengetahui produksi optimum enzim inulinase dari Aspergillus clavatus Gmm 11.3. Produksi dilakukan dalam media yang mengandung inulin sebagai induser (Vandamme \& Derycke 1983). Produksi enzim dan uji aktivitas inulinase berdasarkan penguraian inulin menjadi gula pereduksi diukur dengan metode Nelson Semogyi dengan kisaran waktu 1 sampai 6 hari (Alexander et al, 1985). Ekstrak enzim kasar dipekatkan dengan PEG, selanjutnya enzim diamobilkan dengan karbon aktif. Hidrolisis inulin oleh enzim amobil menggunakan kolom kromatografi bermantel dengan kecepatan alir eluen $1 \mathrm{ml} / 20$ menit dan variasi suhu jaket air yang mengalir $40^{\circ} \mathrm{C}, 50^{\circ} \mathrm{C}$, dan $60^{\circ} \mathrm{C}$. Penentuan kadar protein yang terikat sebelum dan setelah proses hidrolisis didasarkan pada perhitungan protein yang tersisa dilarutan dengan metode Lowry.

Pembuatan Medium Padat Potato Dextrose Agar (PDA ) + inulin. Kentang 200 gram diiris-iris dan dimasukkan ke dalam 500 ml aquades, dididihkan selama 20 menit, kemudian disaring dengan kain kasa. Filtrat yang diperoleh dicampurkan dengan dekstrosa 20 gram dan ditambahkan aquades hingga volume 1000 ml. Kemudian ditambahkan agar 20 gram dan dipanaskan sampai agarnya larut. Kemudian ditambahkan inulin $1 \%$ dalam bufer asatat $0,01 \mathrm{M} \mathrm{pH} 5$ (Zul 1999). Sebanyak $5 \mathrm{ml}$ cairan medium dimasukan ke dalam tabung reaksi tertutup disterilisasi pada tekanan $15 \mathrm{lb}, 121^{\circ} \mathrm{C}$ selama 20 menit di dalam autoklaf. Selanjutnya tabung-tabung tersebut dimiringkan dan dibiarkan membeku.

Pembuatan Medium Cair Untuk Produksi Enzim Inulinase. Inulin 1\% ditambah $\mathrm{MgSO}_{4} 7 \mathrm{H}_{2} \mathrm{O}$ 0,05\%, $\mathrm{FeSO}_{4}$ 0,015\%, $\mathrm{NaCl} 0,2 \%$, dan Tempe 1\% dilarutkan dalam $500 \mathrm{ml}$ aquades dan pH diatur 5 . Selanjutnya ditambahkan aquades sampai volumenya $1000 \mathrm{ml}$. Medium ini dimasukkan ke dalam masingmasing erlenmeyer sebanyak $500 \mathrm{ml}$ dan $50 \mathrm{ml}$ dalam erlenmeyer yang lain, dan disterilisasi dengan autoklaf pada tekanan $15 \mathrm{lb}, 121^{\circ} \mathrm{C}$ selama 20 menit. Medium siap ditanami.

Peremajaan jamur Hasil Isolasi (Saryono et al, 2002). Aspergillus clavatus Gmn 11.3, diambil 1 ose secara aseptis, kemudian diinokulasikan pada medium agar miring, selanjutnya diinkubasikan pada temperatur kamar selama tiga hari.

Produksi Enzim Inulinase. Koloni yang tumbuh pada medium padat hasil peremajaan dari isolat jamur, diambil secara aseptis sebanyak 3 ose dan kemudian dimasukkan ke dalam 2 erlenmeyer $100 \mathrm{ml}$ yang masing-masing berisi $50 \mathrm{ml}$ madium cair. Kemudian diinkubasi di dalam inkubator bergoyang berkecepatan $100 \mathrm{rpm}$, suhu $30^{\circ} \mathrm{C}$, selama 3 hari. Setelah 3 hari masing-masing biakan/kultur ini diinokulasi secara aseptis ke dalam 2 erlenmeyer 1000 ml masing-masing berisi $500 \mathrm{ml}$ medium cair dan diinkubasi dalam inkubator bergoyang, 1 erlenmeyer selama 3 hari dan erlenmeyer yang lain selama 5 hari sesuai dengan produksi optimum yang diperoleh dari pra penelitian. Setelah 3 hari dan 5 hari medium kultur ini dipisahkan dengan sentrifugas dingin, kecepatan 8000 rpm selama 15 menit. Supernatan disaring dengan filter glass fiber (Whatman GF/C) kemudian ditambah $\mathrm{NaN}_{3}$ sehingga konsentrasinya menjadi 0,02\% dalam larutan ekstrak enzim kasar. Ekstrak kasar enzim inulinase ditentukan aktivitasnya dengan metode Nelson- Somogyi ( Amos 1990) dan kadar protein dengan metode Lowry.

Preparasi Tabung Dialisis. Tabung dialisis sebanyak 2 buah disiapkan (ukurannya dapat disesuaikan dengan kebutuhan). Kemudian tabungtabung tersebut dididihkan selama 10 menit (10 menit dalam keadaan mendidih) dalam $500 \mathrm{ml} 2 \% \mathrm{NaHCO}^{3+}$ 1 mM EDTA ( $\mathrm{pH} 8,0)$. Selanjutnya dicuci tabung luar dan dalam dengan aquades dan kemudian dididihkan lagi 10 menit dalam $500 \mathrm{ml} 1 \mathrm{mM} \operatorname{EDTA}(\mathrm{pH} 8,0)$ yang baru. Kemudian disimpan tabung dialisis dalam gelas piala berisi $500 \mathrm{ml}$ aquades dan $0,5 \mathrm{ml}$ kloroform (sebagai bahan pengawet) di lemari es. Gelas piala ditutup dengan parafilm. Sebelum digunakan, bagian dalam dan luar tabung dicuci dengan aquades beberapa kali supaya betul-betul yakin tidak ada lagi klorofrom yang mungkin menempel. Bisa dicuci dengan menggunakan Pasteur pipet dengan mengklem bawahnya 4 kali, lalu dibiarkan berputar di aquades dalam gelas piala $500 \mathrm{ml}$. 
Pemekatan Enzim Menggunakan Polyetilen Glikol. Ekstrak kasar enzim inulinase pada hari ke-3 dan ke-5 dipekatkan dengan PEG (BM 35.000) dengan menggunakan membran selofan. Membran selofan yang berisikan larutan enzim ini diletakkan diatas PEG dalam gelas piala. Kemudian dimasukkan dalam lemari es 34 jam. Apabila PEG tersebut telah basah maka PEG diganti dengan yang baru. Proses ini dihentikan setelah volume larutan enzim di dalam membran selofan telah berkurang/terpekatkan menjadi setengah sampai sepertiga bagian dari volume semula. Enzim inulinase yang sudah dipekatkan dientukan aktivitasnya dengan metode Nelson-Somogyi dan kadar protein dengan metode Lowry.

Amobilisasi Enzim Inulinase. Enzim inulinase pada hari ke-3 dan ke-5 sebanyak $25 \mathrm{ml}$ diencerkan sampai $100 \mathrm{ml}$ dengan buffer asetat $0,01 \mathrm{M}, \mathrm{pH} 5$. Larutan ini ditambahkan karbon aktif dan diaduk secara merata dengan pengaduk magnet, dilakukan pada suhu kamar selama 30 menit (Amos 1990). Jumlah karbon aktif divariasikan dari berat: 1 g; $2,5 \mathrm{~g} ; 5 \mathrm{~g} ; 15 \mathrm{~g} ; 20 \mathrm{~g}$; $25 \mathrm{~g} ; 30 \mathrm{~g}$; dan $35 \mathrm{~g}$.

Pengujian Protein Terikat. Penentuan kadar protein yang terikat dan terlepas didasarkan pada perhitungan protein yang tersisa di larutan setelah proses amobilisasi dan hidrolisis ditentukan dengan metode Lowry seperti dilakukan sebelumnya oleh Amos (1990).

Hidrolisis Inulin oleh Inulinase Amobil. Enzim pada hari ke-3 dan ke-5 yang sudah diamobilkan dipreabsorbsi dengan buffer asetat $0,01 \mathrm{M} \mathrm{pH} 5$, kemudian dituangkan kedalam kolom kromatogarfi sepanjang $20 \mathrm{~cm}$ secara perlahan-lahan kemudian enzim tersebut dielusi dengan buffer asetat $0,01 \mathrm{M} \mathrm{pH}$ 5. Sampel inulin dipreabsorbsi dengan buffer asetat $0,01 \mathrm{M} \mathrm{pH} 5$ dan dimasukkan ke dalam kolom. Sampel dielusi dengan buffer asetat $0,01 \mathrm{M} \mathrm{pH} 5$ dengan kecepatan alir eluen $1 \mathrm{ml} / 20$ menit dengan variasi suhu jaket air yang mengalir $40^{\circ} \mathrm{C}, 50^{\circ} \mathrm{C}, 60^{\circ} \mathrm{C}$. Hasil fraksi tabung yang keluar ditampung sebanyak $3 \mathrm{ml}$ dalam setiap vial. Hasil hidrolisis ditampung dalam 10 vial, kemudian ditentukan aktivitasnya dengan metode Nelson-Somogyi dan kadar protein dengan metode Lowry dari masing-masing vial (Alexander et al, 1985).
Amobilisasi inulinase Aspergillus clavatus Gmn II.3

\section{HASIL DAN PEMBAHASAN}

Produksi inulinase oleh Aspergillus clavatus Gmn 11.3 menghasilkan dua puncak aktivitas, yaitu setelah 3 hari fermentasi dan 5 hari fermentasi (Gambar 1). Hasil ini menunjukkan bahwa Aspergillus clavatus memproduksi dua jenis inulinase. Studi pendahuluan oleh Saryono (2002) menunjukan bahwa kedua enzim ini memiliki berat molekul yang berbeda yaitu 65,2 dan $62,4 \mathrm{kDa}$, tetapi belum diketahui apakah kedua enzim ini memeiliki tipe yang berbeda (ekso atau endoinulinase). Hasil ini sejalan dengan penelitian Ettalibi \& Barrati (1987), yang menemukan endo dan eksoinulinase dari Aspergillus ficuum. Nakamura et al, 1994 mengisolasi dua tipe endoinulinase dari Aspergillus niger mutan 817.

Ekstrak enzim ekstraselular hasil fermentasi hari ke-3 dan hari ke-5 dipekatkan dengan menggunakan Polietilen Glikol untuk mendapatkan aktivitas enzim yang lebih tinggi. Setelah pemekatan aktivitas enzim naik 200\%, seperti dapat dilihat pada Tabel 1 .

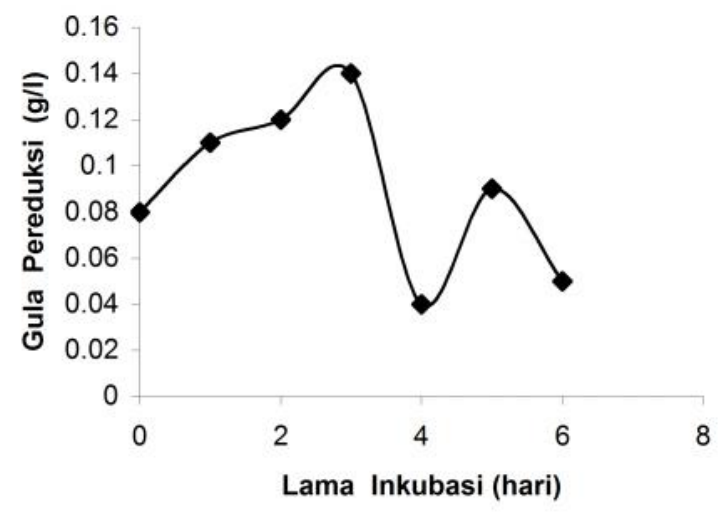

Gambar 1. Produksi Inulinase dari Aspergillus clavatus Gmn 11.3

Tabel 1. Aktivitas inulinase yang dihasilkan

\begin{tabular}{lccccc}
\hline Ekstrak enzim & $\begin{array}{c}\text { Akt. } \\
\text { (unit) }\end{array}$ & $\begin{array}{c}\text { Kons. } \\
\text { Prot. } \\
(\mathrm{mg} / \mathrm{ml})\end{array}$ & $\begin{array}{c}\text { Tot. } \\
\text { Akt. } \\
\text { (unit) }\end{array}$ & $\begin{array}{c}\text { Total } \\
\text { Prot. } \\
(\mathrm{mg} / \mathrm{ml})\end{array}$ & $\begin{array}{c}\text { Akt. } \\
\text { Sp. } \\
(\mathrm{U} / \mathrm{mg})\end{array}$ \\
\hline $\begin{array}{l}\text { Hari ke-3 } \\
\begin{array}{l}\text { a. Ekstrak } \\
\text { kasar } \\
(400 \mathrm{ml})\end{array}\end{array}$ & 0,10 & 0,447 & 40 & 190,8 & 0,2096 \\
$\begin{array}{l}\text { b. Hasil } \\
\text { pemekatan } \\
(200 \mathrm{ml})\end{array}$ & 0,3 & 1,347 & 60 & 269,4 & 0,2227 \\
$\begin{array}{l}\text { Hari ke-5 } \\
\text { a. Ekstrak } \\
\text { kasar } \\
\quad(400 \mathrm{ml})\end{array}$ & 0,05 & 0,232 & 20 & 92,8 & 0,2155 \\
$\begin{array}{l}\text { b. Hasil } \\
\text { pemekatan }\end{array}$ & 0,15 & 0,645 & 30 & 129,0 & 0,2325 \\
$\quad(200 \mathrm{ml})$ & & & & & \\
\hline $\begin{array}{l}\text { Ket. } 1 \text { unit aktivitas }=\text { jumlah enzim yang dapat menghasilkan } \\
\quad 1 \mathrm{~m} \text { Mol fruktosa/jam }\end{array}$ & & & &
\end{tabular}


Kadar protein terikat pada matrik arang aktif optimum pada penambahan $30 \mathrm{~g}$ arang aktif untuk enzim hari ke-3 dan $15 \mathrm{~g}$ untuk enzim hari ke- 5 , seperti ditunjukkan pada Tabel 2 dan Tabel 3. Perbedaan konsentrasi arang aktif ini disebabkan karena kadar protein dan berat molekul kedua enzim ini juga berbeda yaitu 33666,66 $\mu$ g pada hari ke-3 dan 16051,28 $\mu$ g pada hari ke-5. Hal ini mendekati hasil penelitian Amos (1990) yang mendapatkan bahwa berat optimum karbon aktif untuk mengikat protein sebanyak $16307 \mu$ gadalah 15 g karbon aktif. Pada Tabel 2 dan 3 dapat dilihat bahwa jumlah protein terikat bertambah dengan meningkatnya jumlah karbon aktif yang ditambahkan, sampai pada konsentrasi tertentu (30 g pada enzim hari ke-3 dan 15 g pada enzim hari ke-5) kenaikan adsorbsi mencapai kejenuhan.

Hidrolisis inulin menggunakan kolom inulinase amobil dengan kecepatan alir $1 \mathrm{ml} / 20$ menit dan suhu divariasikan $40^{\circ} \mathrm{C}, 50^{\circ} \mathrm{C}$, dan $60^{\circ} \mathrm{C}$. Enzim inulinase hari ke-3 dan hari ke-5 mencapai optimum pada suhu $50^{\circ} \mathrm{C}$, masing-masing pada fraksi ke-4. Suhu $40^{\circ} \mathrm{C}$ belum mampu mencapai hidrolisis maksimum. Hasil penelitian Saryono et al, (2002), mendapatkan suhu optimum enzim inulinase dari Aspergillus clavatus tanpa amobilisasi adalah $50^{\circ} \mathrm{C}$. Dalam hal ini tidak terdapat perbedaan suhu optimum enzim bebas dengan enzim yang diamobilisasi.

Kadar protein terikat setelah hidrolisis. Setelah penggunaan kolom enzim amobil untuk menghidrolisis inulin selama 30 jam, 33,02\% protein enzim hari ke-3 terlepas dari matriknya sedangkan enzim hari ke-5 dengan perlakuan yang sama terlepas lebih banyak yaitu $62,59 \%$. Ikatan enzim dengan matrik amobil relatif lemah, oleh sebab itu pada saat elusi kolom protein enzim ikut terlepas bersama dengan produk. Perbedaan daya ikat enzim hari ke-3 dan hari ke-5 diduga karena ukuran molekul kedua enzim ini berbeda, sehingga mempengaruhi daya ikatnya terhadap matrik arang aktif.

Hasil penelitian ini menunjukkan bahwa enzim inulinase hari ke-3 yang telah diamobilisasi dengan karbon aktif dapat dipergunakan untuk menghidrolisis inulin secara kontinyu dengan waktu alir $1 \mathrm{ml} / 20$ menit dengan suhu $50^{\circ} \mathrm{C}$ sebanyak 3 kali, dengan perkiraan setiap kali hidrolisis 10,08\% enzim telah terlepas dari matriknya. Sedangkan enzim inulinase hari ke- 5 dengan perlakuan yang sama hanya dapat dipergunakan
Tabel 2. Rata-rata protein inulinase hari ke 3 yang terikat karbon aktif

\begin{tabular}{ccc}
\multicolumn{2}{c}{ Kaktif } & \\
aktif $(\mathrm{g})$ & Protein terikat $(\mu \mathrm{g})^{\star)}$ & Persen terikat $(\%)^{\star)}$ \\
\hline 1 & $13239,32^{\mathrm{a}} \pm 46,22$ & $38,75^{\mathrm{a}} \pm 0,11$ \\
2 & $22547,01^{\mathrm{b}} \pm 46,22$ & $65,94^{\mathrm{b}} \pm 0,15$ \\
5 & $26213,68^{\mathrm{c}} \pm 33,92$ & $76,65^{\mathrm{c}} \pm 0,10$ \\
10 & $26811,96^{\mathrm{d}} \pm 55,14$ & $78,43^{\mathrm{d}} \pm 0,12$ \\
15 & $30632,47^{\mathrm{e}} \pm 51,28$ & $89,56^{\mathrm{e}} \pm 0,15$ \\
20 & $33042,73^{\dagger} \pm 40,54$ & $96,60^{\dagger} \pm 0,00$ \\
25 & $33213,67^{\mathrm{g}} \pm 94,55$ & $98,50^{\mathrm{g}} \pm 0,15$ \\
30 & $33666,66^{\mathrm{h}} \pm 53,91$ & $99,98^{\mathrm{h}} \pm 0,06$ \\
35 & $33666,66^{\mathrm{h}} \pm 53,91$ & $99,98^{\mathrm{h}} \pm 0,06$
\end{tabular}

${ }^{\star}$ Harga rata-rata dengan pangkat huruf yang sama tidak berbeda secara nyata pada tingkat $5 \%(P>0,05)$ berdasarkan test Duncan jarak berganda, sedangkan pangkat huruf berbeda adalah berbeda secara nyata.

Tabel 3. Rata-rata protein inulinase hari ke 5 yang terikat karbon aktif

\begin{tabular}{ccc}
\hline $\begin{array}{c}\text { Karbon } \\
\text { aktif }(\mathrm{g})\end{array}$ & Protein terikat $(\mu \mathrm{g})^{\star)}$ & Persen terikat $(\%)^{\star)}$ \\
\hline 1 & $6239,32^{\mathrm{a}} \pm 71,37$ & $38,75^{\mathrm{a}} \pm 0,26$ \\
2 & $10538,46^{\mathrm{b}} \pm 66,62$ & $63,58^{\mathrm{b}} \pm 0,46$ \\
5 & $12341,88^{\mathrm{c}} \pm 40,54$ & $74,43^{\mathrm{c}} \pm 0,17$ \\
10 & $15982,91^{\mathrm{d}} \pm 39,52$ & $96,30^{\mathrm{d}} \pm 0,00$ \\
15 & $16051,28^{\mathrm{e}} \pm 29,92$ & $99,95^{\mathrm{e}} \pm 0,16$ \\
20 & $16051,28^{\mathrm{e}} \pm 29,92$ & $99,95^{\mathrm{e}} \pm 0,16$ \\
25 & $16051,28^{\mathrm{e}} \pm 29,92$ & $99,95^{\mathrm{e}} \pm 0,16$
\end{tabular}

${ }^{*}$ Harga rata-rata dengan pangkat huruf yang sama tidak berbeda secara nyata pada tingkat $5 \%(P>0,05)$ berdasarkan test Duncan jarak berganda, sedangkan pangkat huruf berbeda adalah berbeda secara nyata.

sebanyak 2 kali dengan perkiraan sekali hidrolisis protein yang terlepas dari matrik karbon aktif $20,80 \%$.

\section{KESIMPULAN}

Inulinase dari Aspergillus clavatus Gmn 11.3 dapat diamobilisasi dengan menggunakan arang aktif dengan ukuran 200 mesh sebagai matrik, dimana lebih dari $96 \%$ protein enzim inulinase dapat terikat dengan baik pada matrik. Berat karbon aktif optimum yang dibutuhkan untuk proses amobilisasi inulinase hari ke3 dengan kadar protein $33,66 \mathrm{mg}$ adalah $30 \mathrm{~g}$, sedangkan inulinase hari ke-5 dengan kadar protein $16,06 \mathrm{mg}$ membutuhkan arang aktif $15 \mathrm{~g}$. Hidrolisis inulin menggunakan kolom enzim amobil, mencapai optimum pada suhu $50^{\circ} \mathrm{C}$ dengan kecepatan alir $1 \mathrm{ml} /$ 20 menit. Setelah penggunaan kolom enzim amobil selama 30 jam, sebanyak $66,96 \%$ protein enzim hari ke-3 masih terikat pada matrik, sedangkan enzim hari ke-5 pada kondisi yang sama yang terikat hanya $37,36 \%$. Hal ini menunjukkan bahwa enzim pada hari 
ke-3 terikat lebih baik pada matrik arang aktif dibandingkan dengan enzim hari ke-5.

\section{UCAPAN TERIMA KASIH}

Ucapan terima kasih disampaikan kepada Laboratorium Biokimia Jurusan Kimia FMIPA Universitas Riau atas bantuan fasilitas yang digunakan untuk penelitian ini.

\section{DAFTAR PUSTAKA}

Alexander R.R., Griftith, J.M., \& Wilkinson, M.L. 1985. Basic Biochemical Methods. Singapore: John Willey \& Sons.

Amos. 1990. Amobilisassi enzim invertase dengan menggunakan karbon aktif. Skripsi S1. Pekanbaru: Jurusan Kimia FMIPA Universitas Riau.

Chibata, I. 1978. Immobilized Enzyme: research and development. Tokyo: Kodansha Ltd

Ettalibi M. \& Barrati, J.C. 1987. Purification, properties, and comparison of Invertase, exoinulinase, and endoinulinase of Aspergillus ficuum. J. Appl. Microbiology-Biotechnology 26(1): 13-20.
Mangunwidjaja, D., Suprihatin, \& Sunarti, T.C. 1992 Pendayagunaan inulin dahlia (Dahlian pinnata) untuk ultra high fructose syirup dengan teknik imobilisasi sel Kluyveromyces marxianus dan enzim inulinase. Laporan Penelitian. Fakultas Teknologi Pertanian. Bogor: IPB.

Nakamura T., Nagatomo, Y., Hamada, S., Nisino, Y., \& Ohta, K. 1994. Occurance of two form of extracellular endoinulinase from Aspergillus niger mutant 817. Journal of Fermentation and Biotechnology 78(2): 134-139.

Saryono, Soekartadireja, E.M., Supriatna, \& Hadiman, H.R. 1999. Identifikasi jamur penghasil enzim inulinase pada rizosfir umbi dahlia (Dahlia variabilis). Kongres HITI VII. Bandung.

Saryono. 2002. Pemurnian dan penentuan beberapa sifat inulinase ekstraselular dari isolat jamur lokal yang tumbuh pada umbi dahlia (Dahlia variabilis). Disertasi Pasca Sarjana. Bandung: Universitas Padjajaran.

Saryono, Martina, A., \& Chainulfifah. 2002. Isolasi dan karakterisasi jamur penghasil inulinase yang tumbuh pada umbi dahlia. Jurnal Natur Indonesia. 4(2): 171-177.

Vandamme, E.J. \& Derycke, D.G. 1983. Microbial inulinases process, properties and applications. Adv. Appl. Microb. 29: 139-176.

Winarno, F.G. 1983. Enzim Pangan. Jakarta: Penerbit PT Gramedia.

Zul, D. 1999. Produksi, purifikasi dan karakterisasi inulinase rizosfer Dahlia pinnata. Tesis Pasca Sarjana. Yogyakarta: Program Studi Bioteknologi Jurusan Antar Bidang UGM. 